ISSN 1112-9867

Available online at $\quad$ http://www.jfas.info

\title{
ASSESSMENT OF ATMOSPHERIC POLLUTION IN THE CITY OF NABEREZHNYE CHELNY WITH EMISSIONS FROM MOTOR VEHICLES AND INDUSTRIAL ENTERPRISES
}

\author{
I. F. Suleimanov ${ }^{*}, 1$, G. V. Mavrin ${ }^{1}$, M. R. Kalimulina ${ }^{1}$, E. V. Bondarenko ${ }^{2}$, R. F. Kalimullin ${ }^{2}$, \\ A. A. Filippov ${ }^{2}$ \\ ${ }^{1}$ Kazan Federal University, Naberezhnye Chelny Institute \\ ${ }^{2}$ Orenburg State University
}

Published online: 08 August 2017

\begin{abstract}
The information on existing stationary sources of atmospheric pollution, their qualitative and quantitative characteristics, factual emissions was collected and analyzed within the framework of the present study. On-site investigations of the structure and intensity of the traffic flow on the main thoroughfares of Naberezhnye Chelny were conducted.

Based on the obtained data, a summary calculation of 143 pollutantswas carried out, taking into account those, included in 28 summation groups;maps of distribution of air pollution level throughout the city were drawn and analyzed for each substance, first-ever for Naberezhnye Chelny.

Based on the results of calculation of pollutants dispersion, a forecast was made for the concentrations of pollutants in the residential area of the city. The substances and summation groups, for which maximum permissible concentration is likely to be exceeded (carbonic oxide, nitrogen dioxide and the summation groups, formed by these substances) were detected. Along major automobile highways and interchanges, the zones with expected values of maximum surface concentrations of more than $1 \mathrm{MPC}$ were observed for carbonic oxide.
\end{abstract}

Author Correspondence, e-mail: ecolog_777@mail.ru

doi: http://dx.doi.org/10.4314/jfas.v9i2s.80 
To estimate the relative share of emissions from stationary and mobile sources, the calculation was carried out, without taking into account the vehicles and enterprises of the motor transport complex. It was found, that the calculated emissions of carbon oxide and nitrogen dioxide by stationary sources, in comparison with mobile sources, are not so significant and cause no more than 0.1 MPC.

By the nature of spatial distribution, two distinctly different groups of pollutants were defined: mainly contained in emissions of industrial enterprises, and coming into the atmospheric air, mainly with emissions from automotive transport.

Keywords: emissions fromautomotive transport, maximum permissible concentration, calculation of dispersion, maps of spatial distribution.

\section{INTRODUCTION}

Environmental problems of cities, mainly the largest of them, are connected with the excessive concentration of population, transport and industrial enterpriseson relatively small areas, with the formation of anthropogenic landscapes,far different from the state of ecological balance. The growth of industrial facilities and the constant increase in the intensity of automobile transport are accompanied by a number of negative phenomena and, above all, excessive accumulation of various gas and dusty contaminants in the atmosphere. All of this leads to irreversible destruction of the surrounding landscape and the biosphere as a whole, in large industrial cities $[1,2,3]$.

Naberezhnye Chelny is a city in Russia, located in the north-eastern part of the Republic of Tatarstan, on the left bank of the Kama River. The banks of the river are connected by a dam, with the automobile and railway roads.

Naberezhnye Chelny is a city of republican subordination, the main city of polycentric Naberezhnye Chelny agglomeration and the center of the Nizhnekamsk territorial industrial complex, the thirtieth largest city in Russia, and the second most populous city in the Republic of Tatarstan.

Naberezhnye Chelny is a large industrial center. The main branches are mechanical engineering, electric power industry, construction industry, food and processing industry. The key (town-forming) enterprise is OJSC "KAMAZ", which accounts for almost three-quarters of the industrial output, produced in Naberezhnye Chelny. In the city there is basically a rectangular network of streets. The most intensive motor traffic is along the main highways of the city: Naberezhnochelninsky Avenue, Musa Jalil Avenue, 
Mira Avenue, Motorway No.1, Sarmanovsky Trakt, Hassan Tufan Avenue, Vahitova Avenue, Akademika Koroleva Street.

These highways pass through the city and connect the city center with the residential areas and the industrial zone, thereby fulfilling the functions of intra-urban distribution of mass passenger and freight vehicles, servicing adjacent areas and transporting of people to work places. The total length of the street-road network with asphalt-concrete pavement is $568 \mathrm{~km}$, the length of the main streets of the citywide and regional significance is $358 \mathrm{~km}$.

\section{RESULTS AND DISCUSSION}

Three groups of major highways of the city were surveyed: 1) central; 2) radially concentric (or radially adjacent to the city center); 3) transit. When grouping motorways, the classification was adopted, based on the following factors: the territorial location with respect to the center and the city boundaries, and the degree of use by one or another category of motor vehicles. The examined highways are characterized by different variability of the daily, weekly and annual course of traffic flow intensity [4, 5].

On the central highways of the city on working days, the maximum intensity of traffic flows is observed in the morning $(7.30 \ldots 9.00)$, daytime $(12.00 \ldots$ 13.00) and evening $(16.30 \ldots$ $18.30)$ peak hours. At night hours $(24.00 \ldots 6.00)$ the traffic intensity decreases significantly and makes up $10 \%$ of the average traffic intensity in the daytime hours $(7.00 \ldots 24.00)$. The minimum intensity of traffic is observed in the morning $(3.00 \ldots 5.00)$.

At the weekend,the average traffic flow rate on the central highways is reduced by about a factor of 2, in comparison with the traffic on week days. At the same time, the maximum intensity of traffic flows is observed in the daytime from 11.00 to 15.00 . In the morning from 8.00 to 10.00 the traffic intensity averages $25 \%$ of the daily maximum. At night, the traffic intensity is $20 \%$ of the average traffic intensity in the daytime. The minimum intensity of traffic is observed from 3.00 to $5.00 \mathrm{am}$.

For the secondary motorways of the city, the load is approximately the same, where the largest traffic flow is observed from 6.30 to $8.30 \mathrm{am}$ and from 16.30 to $19.00 \mathrm{pm}$, respectively, before and after working day. At all other times, the loading of motorways is negligible $[6,7,8,9]$.

For a weekly course, a sharp decrease in intensity during non-working days, in the city as a whole, is typical.

In the residential area of the city, the contribution to the total traffic volume of freight transport and buses (the category of vehicles, which is a more powerful source of pollutant 
emissions, compared to passenger cars) is about $11 \%$, that is much less, than the same indicator for the industrial zone (about 24\%). This fact also explains the more complex ecological situation in the surveyed sections of the road network in Naberezhnye Chelny, taking into account the higher pollution level of the air basin of the industrial zone, in comparison with the residential area (due to stationary sources).

At the first stage of the assessment, a summary calculation of the amount of emissions from traffic flows in Naberezhnye Chelny was carried out (Table 1).

Table 1. The number of pollutant emissions by traffic flows in Naberezhnye Chelny.

\begin{tabular}{|l|c|}
\hline \multicolumn{1}{|c|}{ Name of pollutant } & Number of pollutant emissions, tons/year \\
\hline Nitrogen (IV) oxide (Nitrogen dioxide) & 4595,652 \\
\hline Carbon black (carbon) & 88,51 \\
\hline Sulfur dioxide & 466,692 \\
\hline Carbon oxide & 32853,76 \\
\hline Benzo [a] pyrene (3,4-benzo [a] pyrene) & 0,005154 \\
\hline Formaldehyde & 15,23 \\
\hline Petroleum benzin & 2672,51 \\
\hline Kerosene & 576,11 \\
\hline Blend of saturated hydrocarbon C1-C5 & 25,061 \\
\hline Blend of saturated hydrocarbon C6-C10 & 6,912 \\
\hline
\end{tabular}

Pollutants from traffic flows in Naberezhnye Chelny in descending order are the following: carbon oxide (CO) - 32854 tons/year; nitrogen oxides $\left(\mathrm{NO}_{\mathrm{x}}\right)$ - 4596 tons/year; total hydrocarbons $\left(\mathrm{C}_{\mathrm{n}} \mathrm{H}_{\mathrm{m}}\right)$ - 3296 tons/year; sulfur dioxide $\left(\mathrm{SO}_{2}\right)$ - 467 tons/year; carbon $(\mathrm{C})$ - 87 tons/year. Besides oxygen containing, the $\mathrm{C}_{\mathrm{n}} \mathrm{H}_{\mathrm{m}}$ group includes carcinogenic hydrocarbons, represented by benzo $(\alpha)$ pyrene $\left(\mathrm{C}_{20} \mathrm{H}_{12}\right)$.

At the second stage of assessment, emissions from stationary sources of air pollution were considered. In Naberezhnye Chelny, there are about 7,479 stationary sources with an annual rate of pollutant emissions - 14,509 thousand tons. In addition to industrial enterprises, the emissions of 240 parking lots, 193 petrol stations, automobile repair shops andcar washes were taken into account. 
A summary calculation of the dispersion of 143 pollutants, forming 28 summation groups was carried out, and the digital map for the distribution of surface concentrations of pollutants in Naberezhnye Chelny was drawn (Figure 1).

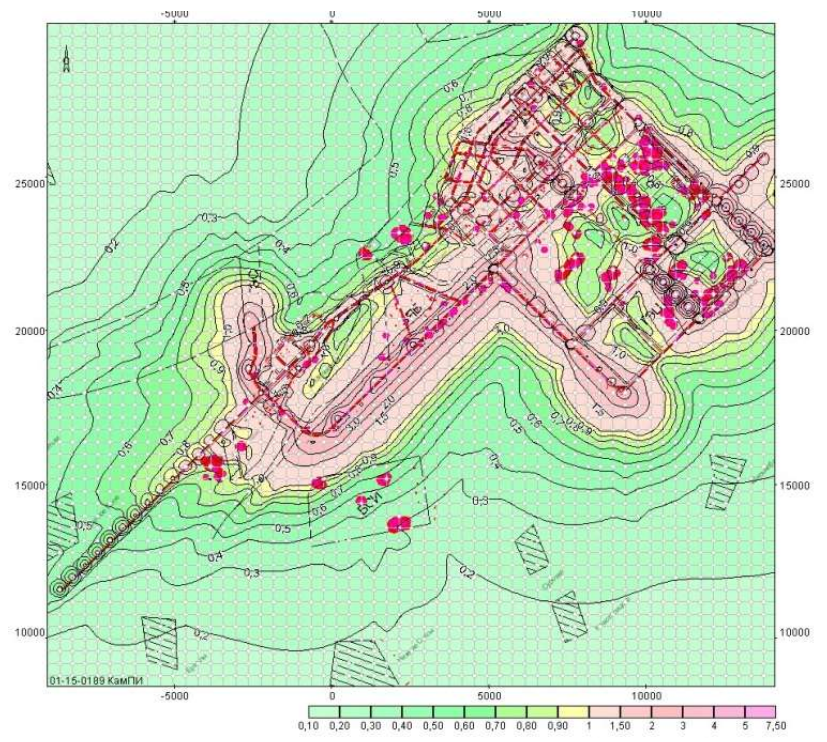

Fig.1. Nitrogen dioxide dispersion map

When performing calculations, the effects of meteorological conditions and terrain relief on the nature of the distribution of pollutants were taken into account. The calculations allowed to obtain the picture of distribution of the atmospheric air pollution level throughout Naberezhnye Chelny $[10,11,12]$.

The exceedanceof carbon oxide concentration, nitrogen dioxide and the summation groups, formed by these substances, in the residential zone of the city, is expected. The zones with the values of maximum surface concentrations of more than $1 \mathrm{MPC}$ are observed for carbon oxide along major automobile highways and interchanges. The exceedance of maximum permissible concentration of nitrogen dioxide is expected in more than $70 \%$ of the territory of Naberezhnye Chelny.

For pollutants, contained in emissions of stationary sources, there is no expectation of exceeding the MPC at the border with the residential area. The highest concentrations in the shares of MPC are predicted for the following substances and groups of summation: manganese and its compounds - 0.66 MPC; sodium hydroxide - $0.6 \mathrm{ppm}$; carbon (carbon black) - 0.31 MPC; dimethylbenzene (xylene) - 0.7 MPC; 1-butanol - 0.35 MPC; phenol $0.26 \mathrm{MPC}$; butyl acetate - 0,6 MPC; acetone 0.2 - MPC; triethanolamine - $0.22 \mathrm{MPC}$; petroleum-based mineral oil - 0.8 MPC; solvent naphtha - 0.6 MPC; abrasive dust- 0,2 MPC; 
summation group 6015 (acetone, furfural, formaldehyde and phenol) - 0.55 MPC; the summation group 6017 (aerosols of vanadium pentoxide and manganese oxides) - 0.65 MPC; summation group 6038 (sulfur dioxide and phenol) - 0.35 MPC; the summation group 6052 (acetic acid, phenol and ethyl acetate) - 0.3 MPC.

To estimate the contribution of stationary sources to pollution of the residential area, a calculation was made without taking into account the traffic flows. It was found, that the calculated emissions of carbon oxide and nitrogen dioxide by stationary sources, in comparison with mobile sources, were not so significant and amounted to no more than 0.1 MPC. This was due to the remoteness of most major stationary sources of air pollution from the residential area, and a lower total emission of these pollutants, compared to motor transport.

For 17 priority pollutants, a decrease of content in the atmospheric airwas observedin proportion to distance from the industrial zone. For nitrogen dioxide and carbon oxide, there was an increase in the calculated concentration at 2 points, located in the central part of the city. An increase in content $\mathrm{CO}$ and $\mathrm{NO}_{\mathrm{x}}$ was recorded in proportion to distance from the industrial zone towards the city center, where the maximum intensity of traffic flows was observed.

\section{DEDUCTIONS}

In the residential area of the city, the contribution to the total traffic volume of freight transport and buses (the category of vehicles, which is a more powerful source of pollutant emissions, compared to passenger cars) is about $11 \%$, that is much less, than the same indicator for the industrial zone (about 24\%). This fact also explains the more complex ecological situation in the surveyed sections of the road network in Naberezhnye Chelny, taking into account the higher pollution level of the air basin of the industrial zone, in comparison with the residential area (due to stationary sources).

Pollutants from traffic flows in Naberezhnye Chelny in descending order are the following: carbon oxide $(\mathrm{CO})$ - 32854 tons/year; nitrogen oxides $\left(\mathrm{NO}_{\mathrm{x}}\right)$ - 4596 tons/year; total hydrocarbons $\left(\mathrm{C}_{\mathrm{n}} \mathrm{H}_{\mathrm{m}}\right)-3296$ tons/year; sulfur dioxide $\left(\mathrm{SO}_{2}\right)$ - 467 tons/year; carbon $(\mathrm{C})$ - 87 tons/year. Besides oxygen containing, the $\mathrm{C}_{\mathrm{n}} \mathrm{H}_{\mathrm{m}}$ group includes carcinogenic hydrocarbons, represented by benzo $(\alpha)$ pyrene $\left(\mathrm{C}_{20} \mathrm{H}_{12}\right)$. 


\section{CONCLUSION}

Based on the results of on-site surveys, the motor roads of Naberezhnye Chelny were divided into groups, according to the composition and intensity of traffic flows, as well as the dynamics of these indicators in the daily, weekly and annual cycles of traffic. The patterns of changes in the composition of the motor transport flow, by groups of automobile highways, have been established.

\section{ACKNOWLEDGEMENTS}

The work is performed according to the Russian Government Program of Competitive Growth of Kazan Federal University.

\section{REFERENCES}

1. Baturin A.P. Optimal development of transport systems: Monograph. - Moscow: Transport, 1991. $-176 \mathrm{p}$.

2. Bezuglaya E.Yu., Rastorgueva G.P., Smirnova I.V. What airis inspired by industrial city? L.: Gidrometeoizdat, 1991. -255 p.

3. Bezuglaya E.Y. Measurement of toxic pollutants in Russian cities and their effect on human health. Measurement of Toxic and Related Air Pollution. USEPA/A and WMA International Symposium. - 1994.

4. Suleimanov I.F., Mavrin G.V., Kharlyamov D.A.An assessment of atmospheric air pollution in industrial city, using computational methods//Book of reports of International Youth Conference (September 12-13, 2012). - Kazan: Publishing house of Kazan National Research Technological University, 2012. - Pp. 454-459.

5. Suleimanov I.F., Mavrin G.V., Makarova I.V. An assessment of air pollution in the city from motor transport and industrial enterprises, on the basis of calculation methods// Scientific journal "Bulletin of Volodymyr Dahl East Ukrainian National University" Lugansk, 2013. - №9 (198). - Part 1. - Pp.139-144.

6. Suleimanov I.F., Mavrin G.V., Kharlyamov D.A., Belyaev E.I., Mansurova A.I. Pollution of the Air Basin in the Cities by Motor Transport and the Industrial Enterprises, Quality Assessment of Atmospheric Air with the Use of Calculation Methods and Instrumental Control // Modern Applied Science; Vol. 9, No. 4; 2015, Pp. 12-20.

7. Khabibullin R.G., Makarova I.V., Belyaev E.I., Suleimanov I.F., Pernebekov S.S., Ussipbayev U.A., Junusbekov A.S., Balabekov Z.A. The Study and Management of 
Reliability Parameters for Automotive Equipment, Using Simulation Modeling// Life Science Journal, 2013; 10 (12s), Pp. 828-831.

8. Yakimov M.R. The concept of transport planning and traffic management in large cities Perm: Publishing House of Perm State Technical University. - 2011. - 175p.

9. Makarova I.V., Belyaev E.I., Mavrin V.G, Suleimanov I.F. City Transport System Improvement through the Use of Simulation Modeling System // International Journal of Applied Engineering Research, Volume 9, Number 22 (2014), pp.15649-15655.

10. Gkritza, K. \& Karlaftis, M.G. Intelligent Transportation Systems Applications for the Environment and Energy Conservation (Part 1). Journal of Intelligent Transportation Systems: Technology, Planning, and Operations. 2013. Vol. 17. Iss. 1. Pp. 1-2.

11. Shimamoto, H. \& Murayama, N. \& Fujiwara, A. \& et.al. Evaluation of an existing bus network using a transit network optimisation model: a case study of the Hiroshima City Bus network. Transportation. 2010. Vol. 37. Iss. 5. Pp. 801-823.

12. Jingxin Xia \& Mei Chen Defining Traffic Flow Phases Using Intelligent Transportation Systems-Generated Data // Journal of Intelligent Transportation Systems: Technology, Planning, and Operations Volume 11, Issue 1, 2007, pp. 15-24.

How to cite this article:

Suleimanov I F, Mavrin G V, Kalimulina M R, Bondarenko E V, Kalimullin R F, Filippov A A. Assessment of atmospheric pollution in the city of naberezhnye chelny with emissions from motor vehicles and industrial enterprises. J. Fundam. Appl. Sci., 2017, 9(2S), 10591066. 